\title{
THE ROLE OF EARTHWORMS IN PASTURE PRODUCTION AND MOISTURE CONSERVATION
}

\author{
S.M.J. STоскDILI \\ Instructor in Agriculture, Department of Agriculture, \\ Palmerston \\ G. G. Cossens \\ Scientist, Invermay Research Station
}

\section{Introduction}

RESEARCH has shown that pasture production on soils without earthworms is limited to considerably less than the true potential.

Increased production with beneficial earthworms is associated with pronounced changes in the physical and chemical properties of the soil. Infiltration rate is increased, moisture is conserved and the risk of soil erosion is reduced

\section{Pasture Production Increases}

The beneficial effects of suitable earthworms have been recognized on a wide range of soils in various parts of New Zealand (Hamblyn and Dingwall, 1945; Nielson, 1951a, b, 1953, 1962; Waters, 1951; Sears and Evans, 1953; Richards, 1955; Stockdill, 1959, 1966).

In trials, the beneficial species, Allolobophora caliginosa has given production increases ranging from $28 \%$ to over $100 \%$.

Nielson $(1951 b, 1953)$ measured increases of $28 \%$ to $110 \%$ from mixed swards. In turf and pot trials he used eight different soils with and without earthworms ( $A$. caliginosa).

Waters (1951), also in pot trials using A. caliginosa, measured increases of $77 \%$ from pure ryegrass and $113 \%$ from the ryegrass component of a grass/ clover mixture. Clover yields were not affected.

Stockdill $(1959,1966)$ was able to measure in the field a pasture production increase of $72 \%$ following the intro- 
duction of earthworms (A. caliginosa) to an otherwise highly-developed pasture on an upland hygrous yellowbrown earth soil near Hindon in Otago.

This Hindon field is of particular interest because it is typical of many thousands of acres that have been or are being developed into sown pastures. It was ploughed from virgin snowgrass (Chionochloa spp.) and fescue tussock (Festuca novae-zealandiae) in 1940, put through a rotation of feed crops, and sown to grass in spring 1943. One ton of burnt lime was applied in 1941 and again in 1943. One ton of ground limestone was applied in 1945. It has been regularly topdressed with superphosphate and has had periodical dressings of DDT and molybdenum.

Earthworms were introduced in October, 1949, to a relatively high producing 6-year-old pasture. Four years later, in September, 1953, green patches of earlier spring growth showed up at each point of introduction. The $72 \%$ increase in production was measured in three cuts taken in spring 1954 from 1 l-year-old pasture.

Since then, earthworms have advanced several chains across the field and in 1965-6 the rate of growth technique (Lynch, 1960) was used to compare production where there are still no earthworms with that in zones where they are well established and where they are just entering. The 22-year-old pasture was topdressed with $6 \mathrm{cwt}$ of DDT superphosphate in September, 1965. Results of three-weekly cuts from then until May, 1966 (Table 1) show an increase of $29 \%$ where earthworms are active and $19 \%$ where they are not yet fully established.

Thus, when earthworms were added to a 22-year-old pasture, heavily topdressed, and producing over $8,000 \mathrm{lb}$ of dry matter, production increased by $29 \%$ or over $2,000 \mathrm{lb}$ of dry matter-or if it could be fully utilized an extra ewe and a half per acre.

TABLE 1: RATE OF GROWTH, DRY MATTER YIELD OF PASTURE AT HINDON, OTAGO, SEPTEMBER, 1965 TO MAY, 1966

\begin{tabular}{|c|c|c|c|c|}
\hline & & No. Worms & Worms Entering & Worms Established \\
\hline$\overline{\text { Spring }}$ & & 2,910 & 3,220 & 3,660 \\
\hline Summer & $\ldots$ & 3,360 & 3,670 & 4,260 \\
\hline \multirow[t]{2}{*}{ Autumn } & $\ldots$ & 2,120 & 3,080 & 2,870 \\
\hline & & 8,390 & 9,970 & 10,790 \\
\hline
\end{tabular}




\section{Beneficial Effects on Soil Fertility}

How do earthworms bring about these substantial increases? The answer lies in the soil.

In the soil without earthworms (Fig. 1), much of the fertility is locked up in the peaty layer of dung and dead plant material that accumulates at the surface. Decomposition is very slow and there is a definite break in the "fertility cycle". With no mixing of the soil, lime, fertilizers and insecticides also remain as a surface veneer. Beneath this, the soil lacks organic material and plant nutrients; it is dry, compact and of poor structure. Moisture penetration and plant root development are severely restricted. In short, without earthworms there is a laminated mor as described by Barratt (1966), with its characteristic shallow organic cycle.

In contrast, a soil from a few yards away but with an active earthworm population (Fig. 2) has what appears to be a strongly granular mull with its much deeper organic cycle and consequent higher fertility.

Where earthworms are active, all dung and dead plant residues are incorporated into the topsoil. They decompose more rapidly to complete the "fertility cycle" in which, according to Sears (1953), "Plant nutrients pass rapidly and frequently from soil to plant to animal to soil and so on." Lime, fertilizers and insecticides are also mixed through the soil thus increasing their effectiveness. Plant growth substances are secreted and pass into the soil. Soil structure, infiltration of rainfall and moisture-holding capacity are all improved resulting in an obviously more friable and moister topsoil with improved root development.

P lant Growth S ubstances

Plant growth substances have been detected in ten earthworm species. Nielson (1965a, b) has shown that these substances are the product of earthworm metabolism, that they are secreted into the alimentary tract, and later voided in the faeces. He found in his tests that fresh casts were active.

Chemical Changes

Soil analyses presented by Stockdill $(1959,1966)$ have confirmed the improved vertical distribution of organic 


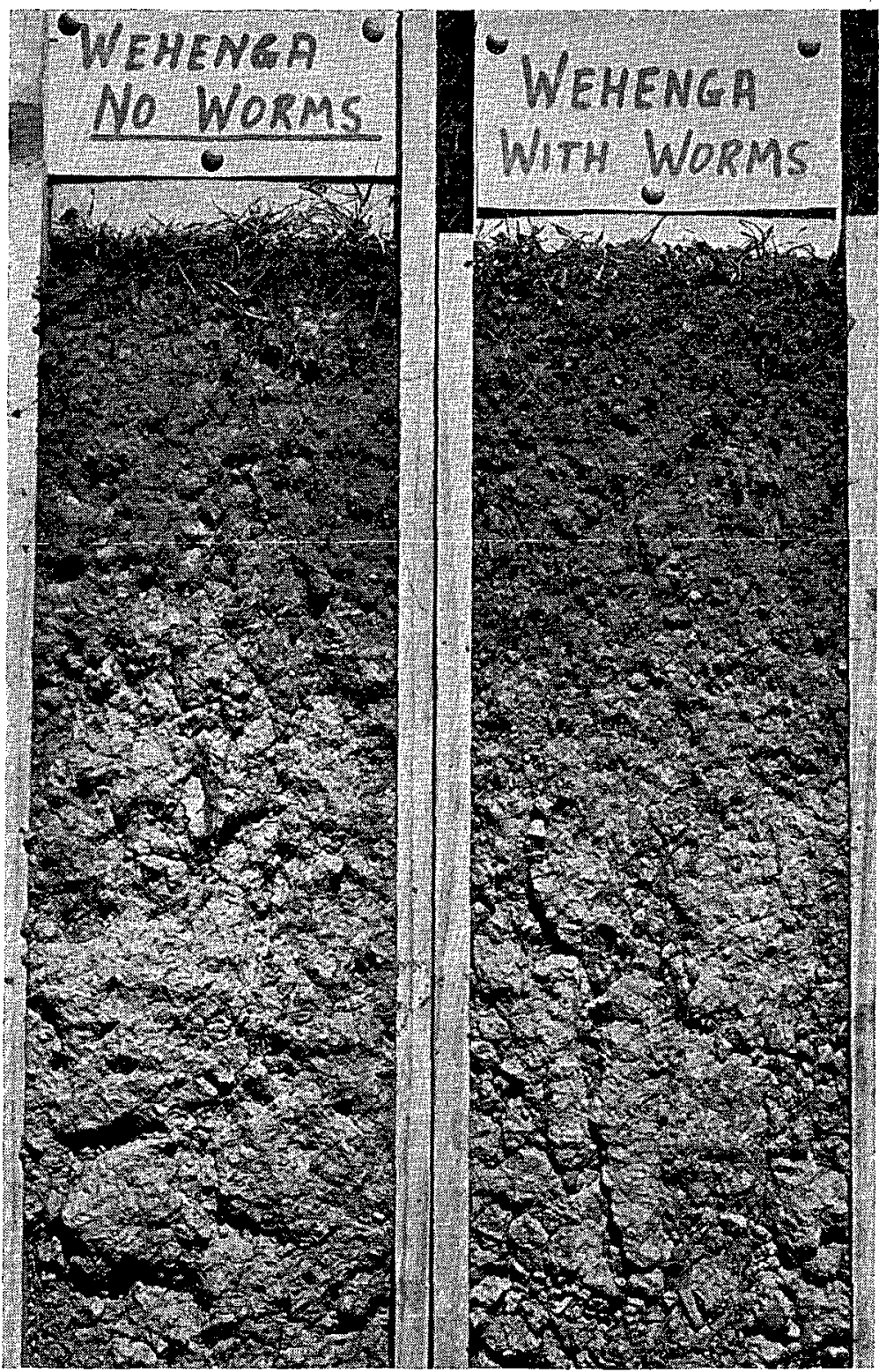

FIG. 1: Soil profile monoliths from 19-vear-old pasture on a hygrous upland yellow-brown earth at Hindon, Otago, Left -without earthworms, organic material accumulates at the surface; soil is compact. Right-with earthworms (A. caliginosa), organic material is removed from the surface and incorporated into the topsoil, physical condition is improved and topsoil is blended with subsoil.

Prepared by E. J. B. Cutler; photo by R. W. Cooper 


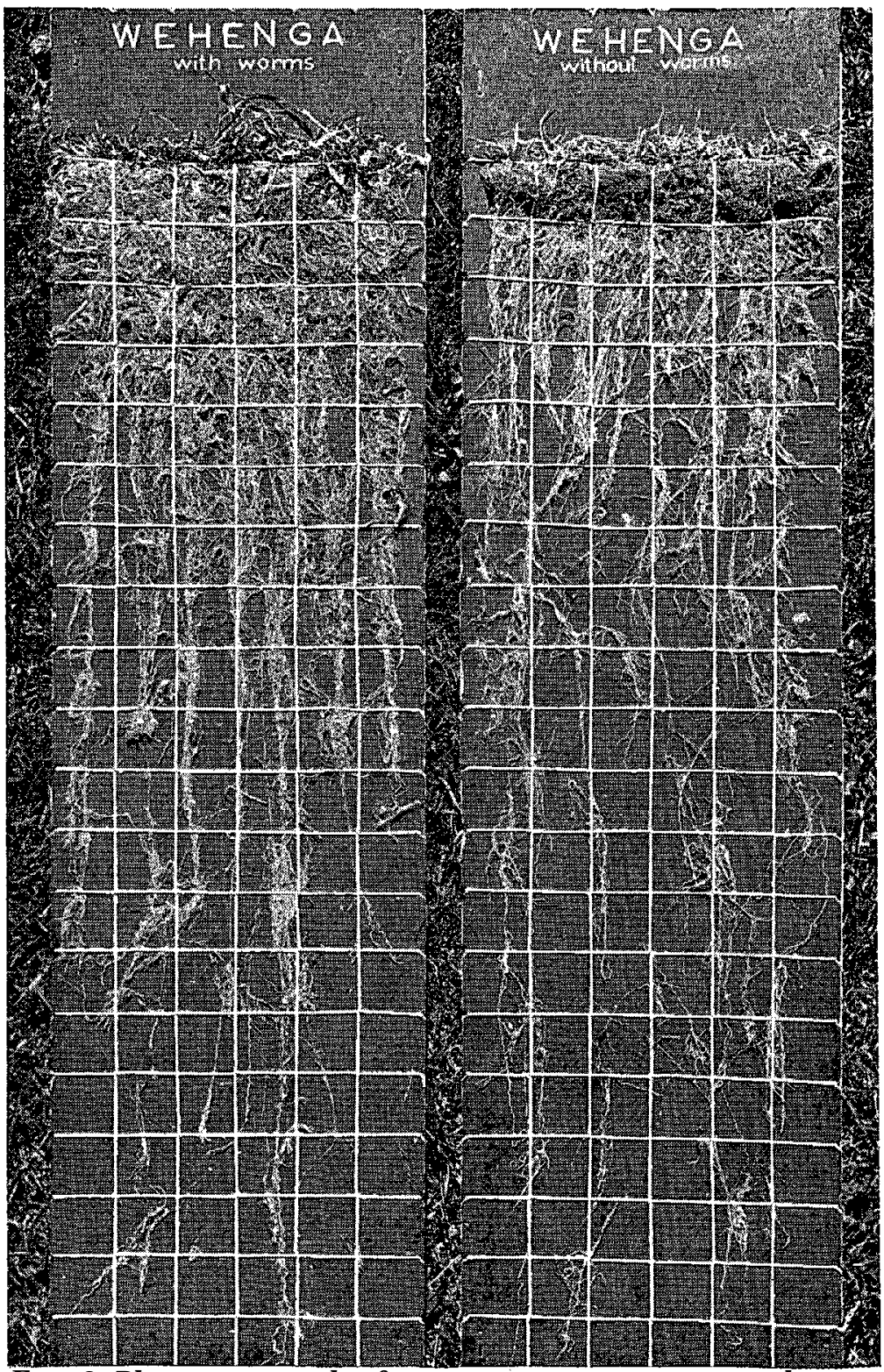

FIG. 2: Plant root samples from 19-year-old pasture on a hygrous upland yellow-brown earth at Hindon, 0 tago. Left - with earthworms (A. caliginosa), root development is improved. Rightwithout earthworms, root development is severely restricted. 
EARTHWORMS AND PASTURE

TABLE 2: EFFECT OF LIME WITHOUT EARTHWORMS FOUR YEARS AFTER APPLICATION (Mean of Three Trials)

\begin{tabular}{cccc}
\hline Depth & Treatment & $\mathrm{pH}$ & Calcium \\
\cline { 2 - 4 } 0 to 1 in. & No lime & 5.4 & 6 \\
& 1 ton lime & 6.1 & 10 \\
1 to 3 in. & No lime & 4.9 & 3 \\
& 1 ton lime & 4.9 & 3 \\
\hline
\end{tabular}

TABLE 3: GRASS-GRUB CONTROL AND VERTICAL DISTRIBUTION OF DDT IN A SUB-HYGROUS YELLOW-GREY EARTH AT NENTHORN, OTAGO, TWO YEARS AFTER APPLICATION

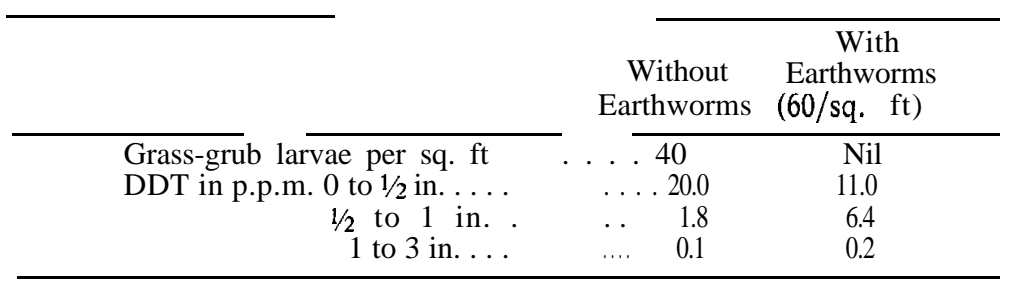

material, fertilizers, lime and DDT in soils with worms. Figures for loss on ignition, organic carbon, nitrogen, cation exchange capacity, total exchangeable bases, percentage base saturation and exchangeable calcium have all been consistent with transfer from the surface to the deeper layers.

The surface veneer effect on soils without worms is particularly noticeable with lime. When applied to the surface lime can be found years later within or beneath the organic mat. In trials, lime at rates up to $40 \mathrm{cwt}$ per acre has had very little effect below the top inch even after 4 to 5 years. Table 2 shows the effect of 20cwt per acre of lime on pH and calcium levels 4 years after application.

Similar surface concentration occurs with DDT and limits its effectiveness against grass-grub (Costelytra zealandica) on some soils without earthworms. Tests on a hygrous upland yellow-brown earth soil at Macraes Flat, Otago, have shown that, 21/2 years after application, 95\% of the DDT present remains in the top half inch. Working with a similar soil, also from Macraes Flat, D. C. F. Perrott (pers. comm.) found that $92 \%$ of grass-grubs exposed to soil from the top inch were affected while soil from the 1 in. to 2 in. and 2 in. to 3 in. depths was toxic to only $8 \%$ and $6 \%$ respectively. 
TABLE 4: PHYSICAL ANALYSES OF SOILS WITH AND WITHOUT WORMS

(Mean of Six Sites)

\begin{tabular}{|c|c|c|c|c|}
\hline Property & \multicolumn{2}{|c|}{ Depth (in.) } & \multirow{2}{*}{$\begin{array}{c}\text { Without Worms } \\
34.9\end{array}$} & \multirow{2}{*}{$\frac{\text { With Worms }}{39.8}$} \\
\hline Field $\overline{\text { capacity }}(\%$ & moisture) & $0-4$ & & \\
\hline & & $4-8$ & 28.8 & 30.5 \\
\hline & & $8-12$ & 24.4 & 25.0 \\
\hline \multirow{3}{*}{\multicolumn{2}{|c|}{15 bar retention ( $\%$ moisture) }} & $0-4$ & 11.4 & 12.2 \\
\hline & & $4-8$ & 9.2 & 9.0 \\
\hline & & $8-12$ & 8.3 & 7.6 \\
\hline \multirow{3}{*}{ Bulk density (g/cc) } & & $0-4$ & 1.05 & 1.05 \\
\hline & & $4-8$ & 1.18 & 1.17 \\
\hline & & $8-12$ & 1.41 & 1.37 \\
\hline \multirow{3}{*}{\multicolumn{2}{|c|}{ Available moisture (inches) }} & $0-4$ & 1.05 & 1.13 \\
\hline & & $4-8$ & 0.91 & 1.00 \\
\hline & & $8-12$ & 0.90 & 0.91 \\
\hline \multirow[t]{3}{*}{ Porosity $(\%)$} & $\ldots$ & $0-4$ & 58.9 & 59.4 \\
\hline & & $4-8$ & 55.2 & 55.7 \\
\hline & & $8-12$ & 47.4 & 49.0 \\
\hline \multirow[t]{3}{*}{ Macroporosity $(\%)$} & & $0-4$ & 24.0 & 18.0 \\
\hline & & $4-8$ & 21.8 & 20.4 \\
\hline & & $8-12$ & 13.4 & 16.0 \\
\hline \multirow{3}{*}{ Organic carbon $(\%$} & byvolume) & $\mathrm{O}-4$ & 3.19 & 3.57 \\
\hline & & $4-8$ & 2.21 & 2.22 \\
\hline & & $8-12$ & 0.99 & 1.15 \\
\hline \multicolumn{5}{|l|}{ Infiltration (inches) } \\
\hline $5 \mathrm{hr}$ intake & $\ldots$ & & 6.46 & 12.20 \\
\hline Basic rate/hr & $\ldots$ & & 0.37 & 0.63 \\
\hline
\end{tabular}

The problem of poor grass-grub control associated with surface concentration of DDT is also reported by Doak (1962, 1963, 1964) for two North Island volcanic soils. From his reference to "poor earthworm activity" and a "peaty top soil overlay" it appears likely that no beneficial earthworms were present.

A comparison of parts of a field with and without earthworms, two years after DDT application (Table 3), indicates that earthworms do in fact influence the downward movement of DDT and improve its effectiveness.

Physical Changes and Moisture Conservation

The physical properties of soils with and without worms have been examined at six sites, on various soil types, at Hindon, Nenthorn and Moonlight. Mean results for the six sites are given in Table 4 for the 0 to 4 in., 4 to 8 in., and 8 to 12 in. depths. Because of the age of the pasture and 
length of residence of the worms vary considerably from site to site, details of two of the soils with a history of at least ten years established worm activity are given in Table 5. The other soils have pastures or worm activity much younger than this.

Because of its complicating effect in comparing the properties of wormed and unwormed sites, the turf mat developed on unwormed sites has been removed in most cases. The physical properties of the wormed and unwormed sites as given in Tables 4 and 5 are the properties of the A and of part of the B soil horizons; the organic horizons are omitted save in the infiltration measurements. Generally it may be said that water held in the turf mat above the mineral soil is not fully available to the plant.

In Table 4 the most marked feature is the increase in the field capacity at all depths to 12 in. on sites with worms as compared with those without. The bulk density and 15 bar moisture retention (or wilting point) remain very similar on soils with worms and without indicating that the increase in field capacity is a reflection of the increased organic matter and improved structure with worms. The increase in available moisture is consequent on the increase in field capacity. Total porosity is much the same with worms as without but the macroporosity shows a reduction in the top 4 in. of soils following worm activity. This would indicate soil structural rearrangement on the wormed sites and this is borne out by the infiltration data which show that the initial 5-hour intake of water is doubled on the wormy soils as is the basic infiltration rate.

All of these property changes are shown to be increased the longer the period of worm activity. In Table 5 the effect of the lo-year activity of beneficial worms is shown in detail for a hygrous yellow-brown earth and for a sub-hygrous yellow-grey earth. In both soils with worms the increase of $17 \%$ in the field capacity-probably owing to increased organic matter and improved structure-and the increase in the bulk density give a 0.7 in. increase in available moisture for the 0 to 12 in. soil depth over the soils without worms. The "tussock" site quoted in Table 5 generally has properties which lie between the site with worms and that without. This again is the result 
of increased organic matter and better soil structure over the pasture site without worms.

The basic infiltration rates are doubled on soils with worms as also is the initial 5-hour intake of water. The greatly increased rates of water intake with worms are a reflection of improved structure. While the basic rate for the "tussock" site is much the same, the 5-hour intake is much higher than on the pasture site without worms.

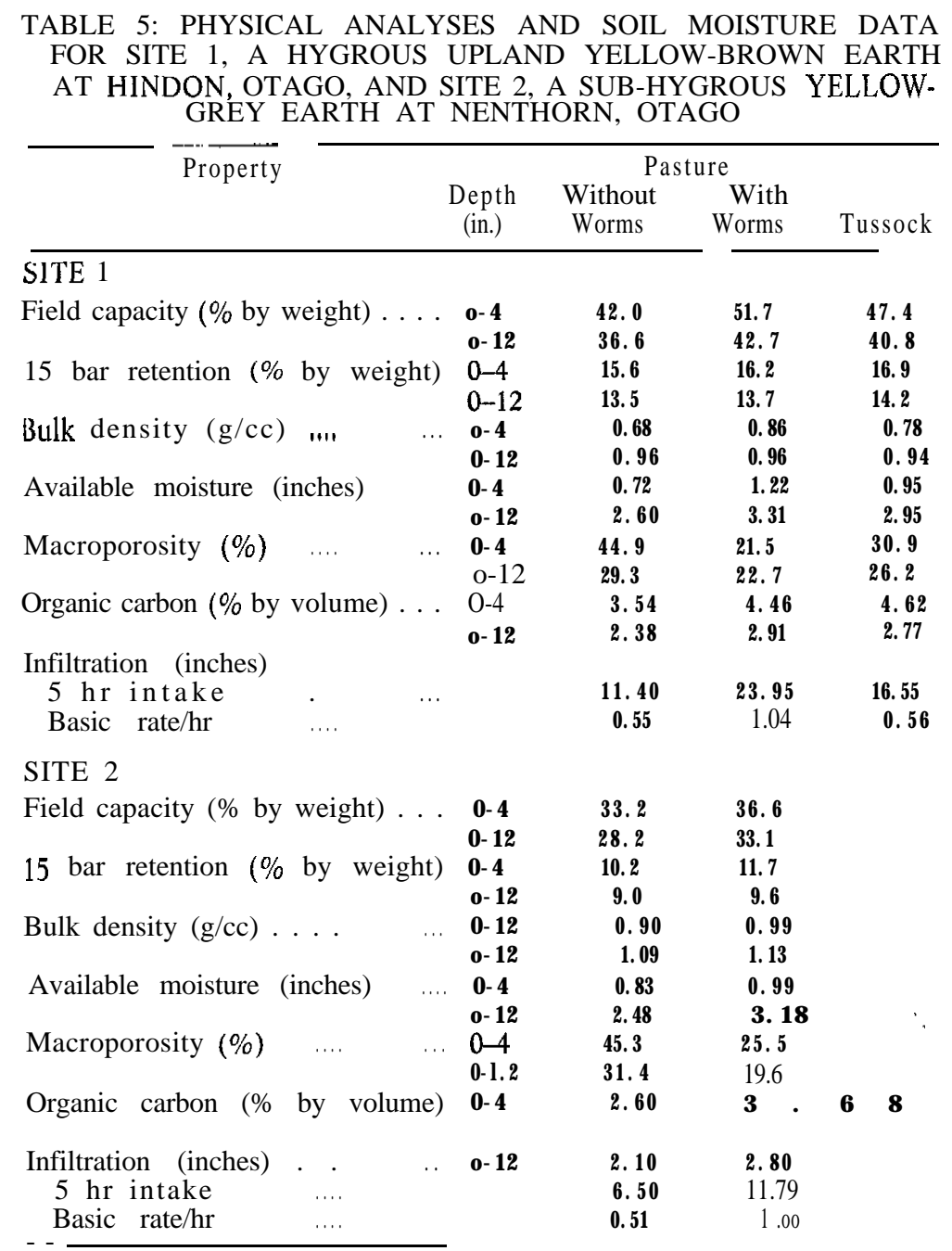


The "tussock" infiltration is, however, lower than on the pasture site with worms.

The macroporosity in the sbils with worms has decreased considerably and this at first sight is difficult to reconcile with the increased infiltration rate. However, as already mentioned, the structure has improved in the presence of earthworms and it is likely that there are fewer macropores of greater diameter in the soils with worms, thus allowing freer movement of water through the profile particularly in the top 12 inches of soil.

Where tussock areas are developed into sown pasture without worms, it follows that, because of the decrease in available moisture storage and slower infiltration, there could be significantly increased run-off with consequent increased risk of erosion and flooding. It is suggested that the gullies in such areas should be left in tussock and improved by oversowing and topdressing. With the encouragement of beneficial earthworms, run-off could be controlled and moisture conserved and subsoiling and contouring may be unnecessary.

\section{Pasture ROOT DEVELOPMENT}

Improved soil structure, better moisture penetration, deeper incorporation of plant nutrients and organic material and better control of grass-grub all contribute to greatly improved root development (Fig. 3). This further reduces susceptibility to drought, enables better utilization of nutrients and makes production over high and low rainfall periods more uniform.

\section{Less Desirable Effects}

Earthworms have a few less desirable effects that are common to most high-fertility soils. These are part of the price that must be paid for higher fertility and increased production.

\section{INCREASED LEACHING}

In the early stages of earthworm activity, the improved movement of lime from the surface into the topsoil must be regarded as beneficial. However, as this downward movement continues, hastened by the higher infiltration rate, it must amount to increased leaching. Analyses (Stockdill, 1966) have confirmed lower $\mathrm{pH}$ and calcium 


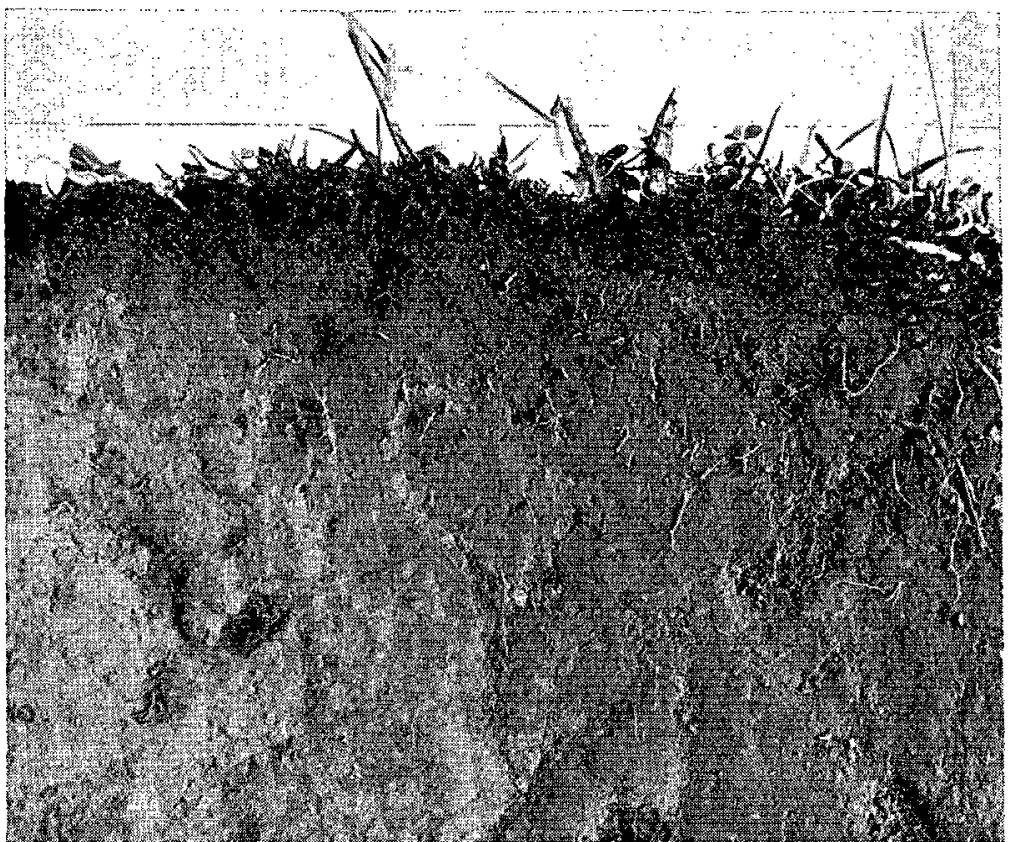

FIG. 3: Soil without beneficial earthworms showing mat of organic material at surface and compact dry nature of the soil beneath.

Photo by $K$. Shca

levels where earthworms have been active for many years. It follows that soils with worms will require a higher level of maintenance liming than those without.

\section{INCREASED PUGGING}

With the turf mat replaced by a mantle of worm casts, the moister more friable topsoil must be more prone to pugging in wet weather. And, possibly of more significance to the mechanized farmer, vehicles are more likely to get bogged in soils with earthworms.

TEETh WeAR

Wear in sheep's teeth will almost certainly increase with earthworm activity. Healy and Ludwig (1965) have shown that teeth wear is directly related to the amount of soil ingested by the grazing animal. They found wear was greatest in July-October when pastures were short and earthworm casts were abundant. 


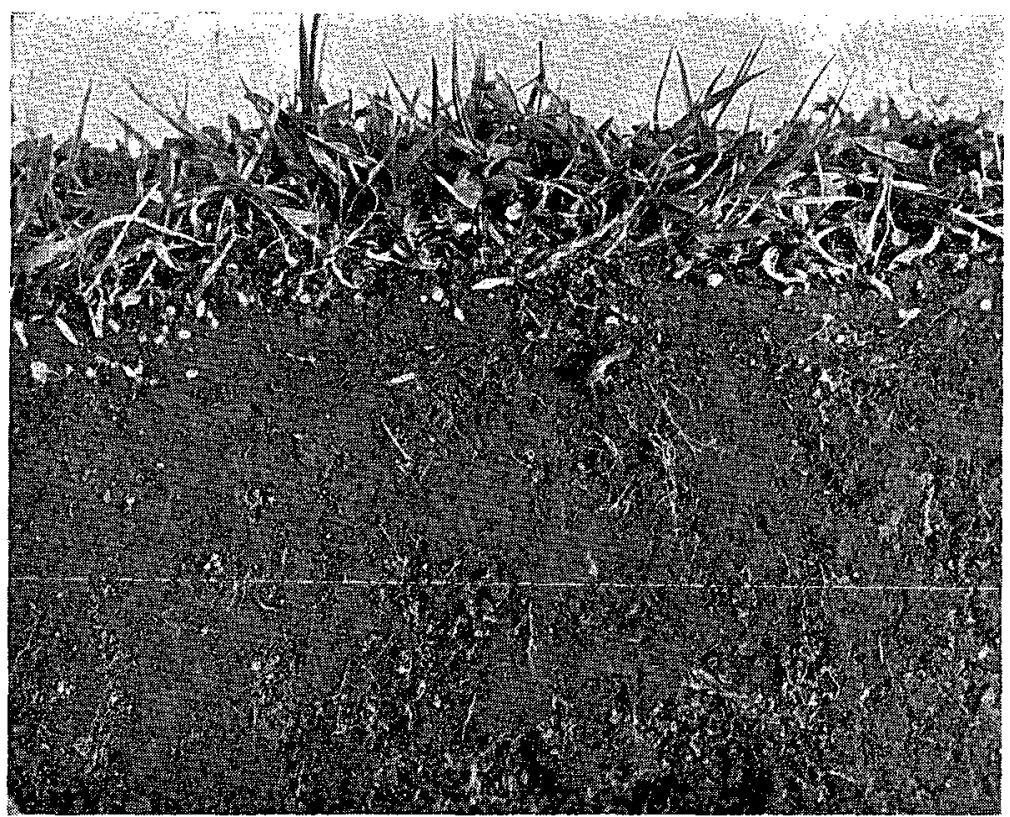

FIG. 4: Soil with earthworms (A. caliginosa). O rganic material has been incorporated into the soil which is moister and more friable.

\section{Beneficial Species and Distribution}

Of over 180 species recognized in New Zealand (Lee, 1959), only very few introduced species are known to improve pasture production.

Of these, Allolobophora caliginosa is by far the most widely distributed, and where conditions are suitable it usually dominates the population. One or two other introduced species may be beneficial but are of lesser importance.

Species that are not beneficial are important, however, in that one or other of them occurs in most places, thus giving the misleading impression that introduction of beneficial species is not necessary.

Beneficial earthworms are absent from many undeveloped soils because calcium levels are too low, 4 m.e. $\%$ or less (Nielson 1951a, 1962). In some areas, inadequate soil moisture has limited either the extent or density of populations. 
The invasion of improved grasslands by beneficial species has been largely a matter of accident. Very few land developers have deliberately introduced earthworms as part of their development programme. Many still subscribe to the view that earthworms will come in when conditions are made suitable for them. And yet it is known that under reasonable conditions natural spread is limited to about $1 / 2$ chain per annum, slightly more under high rainfall, less under low rainfall.

It is not surprising then that considerable areas of otherwise highly developed land have remained unpopulated, often for well in excess of 20 years. R. L. Nielson (pers. comm.), For instance, estimates that about half of Rotorua County is not populated although there is evidence that conditions are suitable for the beneficial species. Most development areas in the South Island are in the same deficient state.

There are probably much greater areas where the effectiveness of beneficial species is limited by marginal calcium or moisture levels.

\section{Stimulating Earthworm Population}

Nielson (1951a, 1962) has shown that A. caliginosa requires a soil calcium level of at least 5 m.e. \% and that populations increase with higher calcium levels. In a pot trial lasting 10 months, numbers of A. caliginosa increased from reproduction alone by $50 \%$ in response to 1 ton of lime and $90 \%$ in response to 2 tons.

Five field trials in the Palmerston area of Otago support this evidence. Earthworms increased by $50 \%$ on plots limed at 1 ton per acre and pasture responses were associated with improved soil moisture.

It follows that a reassessment of lime requirement may be necessary on some soils where present recommendations have been based on trials conducted in the absence of earthworms.

Moisture is also important and, in dry areas, irrigation stimulates earthworm activity and spread.

\section{Introducing Beneficial Earthworms}

A simple low-cost method of introducing earthworms. has been evolved making use of present knowledge of the requirements and behaviour of the beneficial species, $A$. culiginosu. 
It is known that high calcium and adequate moisture favour reproduction which takes place mainly in the spring; that under moist conditions most of the worms are close to the soil surface and that when the topsoil dries out they go deeper into the soil. It is known also that introduced worms, once established, spread about half a chain a year.

Before attempting introduction, it must be established that beneficial species are not already present and that the soil calcium has been raised to a satisfactory level by liming.

Then a suitable source of the species $A$. caliginosa is required. Populated areas are often found near shelterbelts or old steadings where worms have probably come in with soil adhering to plants etc. Populations will be higher in well limed sites and could if necessary be built up by heavy liming. Under moist conditions square spade sods 3 in. deep should contain 15 to 30 worms.

These should be transferred to the introduction area in early spring when soils are moist and when they are unlikely to dry out quickly. Placed half a chain apart each way, 40 sods will cover an acre, and under reasonable conditions, numbers should build up in about 5 years and spread over the area.

If sods are merely placed on the surface, the worms quickly move into the moist soil beneath and survival has been almost as good as from digging the sods in. A pplication of a pound or so of lime to the square yard at each site has greatly improved establishment.

Using this method, three men with a truck should be able to cover 15 to 20 acres a day, and with some mechanization of the turf-lifting a greater area could be covered.

Soil moisture at and following introduction is critical and in drier areas establishment could be better if sods were placed along contour rip marks or furrows put in earlier to trap run-off, but this aspect has not been investigated.

\section{Conclusion}

The research results reported show worthwhile production increases associated with earthworm activity. Even more important is the fact that, without earthworms, ex- 
penditure on land development, seed, fertilizer, lime, fencing etc. can yield only part of the true potential.

The improved infiltration rates mean not only better utilization of rainfall on soils with worms but also increased run-off and the risk of erosion on the extensive areas being developed into pasture without earthworms.

Introduction of earthworms is a relatively simple and low-cost operation that should be part of every land development programme on soils not already populated.

From a soil and moisture conservation viewpoint, introduction and stimulation of earthworms should be encouraged in all conservation programmes.

\section{Acknowledgements}

Assistance received from the following people is gratefully acknowledged: R. L. Nielson for instigation of the trial introduction at Hindon and continued advice; Dr K. E. Lee for identification of species; E. J. B. Cutler and I. B. Campbell of Soil Bureau, for preparation of soil and plant root monoliths and advice on soil types; D. C. F. Perrott, of Entomology Division, for grass-grub investigations; D. S. Rickard and other staff of soil testing laboratories for analyses and advice; field research staff of the Department of Agriculture for field work in physical analyses and rate of growth measurements; and farmers whose cooperation made the research work possible.

\section{REFERENCES}

Barratt, Bcryl C., 1966: Proc, N.Z. ecol. Soc., No. 13:24-9.

Doak, B. W., 1962: Ann. Rep., N.Z. Fert. Manuf. Res. Assn., 1961-2: 22. 1963: ibid., 1962-3:25.

1964: ibid., 1963-4:25.

Hamblyn, C. J.; Dingwall, A. R., 1945: N.Z. I. Agric., 71: 55-8.

Healy, W. B.; Ludwig, T. G., 1965: N.Z. J. agric. Res., 8:737-52.

Lee, K. E., 1959: N.Z. Dept. Sci. Indust. Res. Bull. 130.

Lynch, P. B., 1960: N.Z. Dept Agric. Bull. 399:74-8.

Nielson, R. L., 1951a: N.Z. J. Agric., 83:433-5. 1951b: Proc. 13th Conf. N.Z. Grassl. Ass.: 158-67. 1953: N.Z. J. Agric., 86:374

1962: Unpubl. rep. to Director, Farm Advisory Div., Dept. of Agric.

1965a: Presence of plant growth substances in earthworms demonstrated by paper chromatography and the Went pea test. Nature (in press).

press) 1965b: Growth substances in earthworms. N.Z. J. agric. Res., (in 
Richards, J. G., 1955: N.Z. J. Agric., 91:559

Sears, P. D., 1953: N.Z. J. Sá. Tech., A35:221-36.

Sears, P.D.; Evans, L. T., 1953: N.Z. J. Sci. Tech., A35 (Suppl. 1) : 42-52.

Stockdill, S. M. J., 1959: N.Z. J. Agric., 98:227-33.

- 1966: Proc. N.Z. ecol. Soc. No. 13:68-75.

Waters, R. A. S., 1951: Proc. 13th Conf. N.Z. Grassl. Ass.: 168-75.

\section{DISCUSSION}

$D D T$ is less effective against grass-grub on sails without earthworms because if is concentrated at the surface Does this mean that it will be more effective against porina on these soils?

Yes, there is some evidence that DDT is more effective against porina caterpillar on soils without earthworms. Farmers using DDT have obtained several years' protection against porina on these soils, but on soils with earthworms, DDT has not always remained effective for as long. Without earthworms, DDT remains concentrated at the soil surface where the young porina caterpillars come in contact with it. With earthworms, the DDT is mixed into the soil where it is possibly less effective against porina but definitely more effective against grass-grub.

Grass-grubs in large numbers do a lot of soil mixing; would they have a similar effect to that of earthworms in breaking down the turf mat?

No. We have a very good example at Macrae's Flat where we have been able to observe the effects of up to 150 grass-grubs per square foot over several years. We still have the turf mat and beneath it the soil is structureless. Grass-grubs feed on plant roots, destroy the soil structure and reduce production whereas earthworms feed on dead plant material and organic matter, improve soil structure and increase production. 